\title{
Analysis of Expectations and Perceptions of the Customers in Sports and Healthy Life Centers for Service Quality (Sample of Afyonkarahisar Province)

\author{
Yasir KOÇAK ${ }^{1}$, Uğur TUKUL ${ }^{1}$, Betül TOLAN ${ }^{1}$, Hüseyin GÜMÜŞ${ }^{2}$, Ersan TOLUKAN $^{3}$
}

\begin{abstract}
The purpose of this study is to analyze the expectations and perceptions of the fitness center customers related with the quality of service in Afyonkarahisar. A total of 340 participants (age: $25.03 \pm 13.34$ ), including 171 men (age: $23.51 \pm 12.67$ ) and 169 women (age: $26.57 \pm 13.85$ ) who used 11 different wellness centers in Afyonkarahisar were included in the study. The "Service Quality Assessment Scale" (LSP) developed by Lam (2000) and adapted by Turkish Gurbuz, Koçak and Lam (2012) was used as a data collection tool in the research. The HDQÖ consists of 4 sub-dimensions (personnel, program, locker rooms, facility) and a total of 34 articles. The scale is in likert type of 5 (1: I definitely do not participate, 5: I definitely Participate) and measures the expectations and perceptions of the participants from the wellness center. Independent samples ttest, descriptive statistics and One way Variance Analysis (ANOVA) were used in the analysis of the data. According to the research findings, there was no statistically significant difference between the marital status and educational status ( $p>0.05$ ), while there was a significant difference in the Service Quality Evaluation Scale scores of the participants in terms of age, gender, monthly income, duration of membership and the frequency of using the facility $(\mathrm{p}<0.05)$.
\end{abstract}

Keywords: Service Quality, Expectation, Perception, Healthy Life Center

\section{Spor ve Sağlıklı Yaşam Merkezlerinde Hizmet Kalitesine Yönelik Müşterilerin Beklentilerinin ve Algılarının Analizi (Afyonkarahisar İli Örneği)}

$\ddot{O} z$

Bu çalışmanın amacı, Afyonkarahisar ilinde fitness merkezi müşterilerinin hizmet kalitesine yönelik beklenti ve algılarının incelenmesidir. Araştırma Afyonkarahisar ilinde bulunan 11 farklı sağlıklı yaşam merkezini

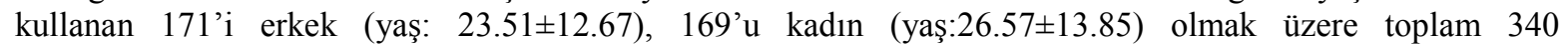
(yaş:25.03 \pm 13.34 ) katılımcı dâhil olmuştur. Araştırmada veri toplama aracı olarak Lam (2000) tarafindan geliştirilen ve Türkçe uyarlaması Gürbüz, Koçak ve Lam (2012) tarafindan yapılan "Hizmet Kalitesi Değerlendirme Ölçeği” (HKDÖ) kullanılmıştır. HDKÖ 4 alt boyut (personel, program, soyunma odaları, tesis) ve toplam 34 maddeden oluşmaktadır. Ölçek 5'li likert tipinde olup (1: Hiç Katılmıyorum, 5: Tamamen Katılıyorum) katılımcıların üyesi oldukları fitness merkezinden duydukları beklenti ve algılarını ölçmektedir. Verilerin analizinde betimleyici istatistik ve tek değişkenli varyans analizi (ANOVA) ile ilişskisiz örneklemler T-Tesi (Independent Samples T-Test) yöntemi kullanılmıştır. Araştırma bulgularına göre katılımcıların Hizmet Kalitesi Değerlendirme Ölçek puanlarında yaş, cinsiyet, aylık gelir, üyelik süresi ve tesisi kullanım sıklığı açısından anlamlı farklılık tespit edilirken $(\mathrm{p}<0.05)$, medeni durum ve eğitim durumları arasında istatistiksel açıdan anlamlı farklılık olmadığı tespit edilmiştir ( $\mathrm{p}>0.05)$.

Anahtar Kelimeler: Hizmet Kalitesi, Beklenti, Algı, Sağlıklı Yaşam Merkezi

\footnotetext{
*This research presented as a poster presentation at 2nd International Sports Science, Tourism and Recreation, Student Congress on 28-30 May 2015 in Afyonkarahisar/TURKEY.

${ }^{1}$ Afyon Kocatepe University, Physical education and sport school, Afyon/TURKEY e-mail: kocaryasir@gmail.com

${ }^{2}$ Mersin University, Physical education and sport school, Mersin/TURKEY.

${ }^{3}$ Yıldırım Beyazit Üniversity, The Faculty of Health Sciences, Department of Sport Sciences, Ankara/ TURKEY.
} 


\section{INTRODUCTION}

Large companies in the service sector are aware that superior service quality will provide competitive advantage to them by creating a high sales and profit potential (Y1ldiz et al., 2013). As a matter of fact, it is known that the service quality has positive effects on customer satisfaction (Temizkan et al., 2016; Murray and Howat, 2002). Organizations that are aware that must be aware of their expectations, provide quality education and constantly develop individualfocused services in order to provide satisfaction of individuals, can obtain consequences in providing competition advantage in this field (Demir, 2013). While quality and performance indicators in manufacturing enterprises are easy to identify and measure, these measurements are more difficult in service enterprises. Because the benefit gained by the concept of service is difficult to assess with quantitative criteria (Eleren and Kılıç, 2007). Service is stated as the integrity of the concrete activities forming benefit and satisfaction and no requiring ownership of any goods and is offered to sale at a certain price to meet the needs of people (Ersoz et al., 2009). According to another definition, it is defined as any activity or benefit in concrete form and its ownership can not be transferred to another party and is offered by one party to other party (Yildiz et al., 2013). Although specific techniques and concepts are taken from the manufacturing sector in order to determine the level of customer satisfaction, production, presentation in the service sector, it is necessary to show some special efforts in order to increase the quality of service because sports services have different characteristics. These features can be ordered as follows;

The fact that sports services do not depend on a physical entity (it is concrete)

$>$ The simultaneous production and consumption of sports services,

$>$ The sports services are unstable and can not be stored (it is only reproducible)
Sports services can not be isolated from the production stage and play an important role in the provision of services,

$>$ Inability to perceive that the service given by the person who provided the sport service is a "product"

> In sporting services, the ability of those who offer the service influence the purchase,

$>$ The ease of transportation to the place of sport services affects the purchase,

D The physical appearance of the facility where sports services are offered influences the purchase,

The period of time when the sport service is offered affects the purchase (Çimen and Gürbüz, 2007).

The concept of quality in the service sector is a more difficult concept to define and measure than other sectors. Therefore, to analyze the quality of service with proper models and methods is important in terms of measuring service quality accurately and directing the management of enterprises (Kılıç ve Eleren, 2010). In recent years, many studies have been conducted to measure service quality and customer satisfaction. The purpose in measuring service quality and customer satisfaction is to increase customer satisfaction and service quality by activating all units of the management for meeting customer expectations (Yerlisu et. al., 2012). As days pass, the quality of service offered by the sectors to the customers increase. Customers are now oriented to organizations that offer services with better quality. Accordingly, organizations are also competing to offer better quality services to their customers in order to become preferred (Ceylan et al., 2010). The "quality dimensions", which have become important for the development of quality sports service and for the establishment of quality standards at some points, should be taken into consideration by the sports service operators by increasing the satisfaction level of the sports service which is a part of the service sector, to increase the demand or at least to sustain the current demand (Çimen, 2003). Thus, the positive effects of sports and wellness centers on stress, depression, quality 
Koçak, Y., Tukul, U., Tolan, B., Gümüş, H., Tolukan, E. / Analysis of Expectations and Perceptions of the Customers in Sports and Healthy Life Centers for Service Quality (Sample of Afyonkarahisar Province)

of life, self-esteem, etc. have been revealed with studies (Y1ldırım et al., 2015; Y1ldırım et al., 2016; Iş1k et. al., 2016).

To become aware how satisfied individuals are with quality service, which plays an important role in meeting customer expectations in the sport sector and increasing satisfaction, is extremely important in terms of being preferable in organizations. Therefore, the purpose of this study is to examine the expectations and perceptions of the customers in the sports and fitness centers regarding the quality of service

\section{METHOD}

\section{Participants}

The study consists of 340 people using 11 fitness centers in Afyonkarahisar province.

\section{Data Collection Tools}

The demographic information form developed by the researchers and used by the researchers

\section{FINDINGS}

Table 1. Distribution of Features Related with Demographics data of Participants

\begin{tabular}{|c|c|c|c|}
\hline Variables & & FREQUENCY (F) & Percentage (\%) \\
\hline \multirow{2}{*}{ Gender } & Male & 171 & 50.3 \\
\hline & Female & 169 & 49.7 \\
\hline \multirow{2}{*}{ Marital status } & Single & 252 & 74.1 \\
\hline & Married & 88 & 25.9 \\
\hline \multirow{3}{*}{ Age } & $<25$ years old & 210 & 61.8 \\
\hline & $25-35$ & 90 & 26.4 \\
\hline & 35 years old and over & 40 & 11,8 \\
\hline \multirow{3}{*}{ Monthly Income } & 1500 & 143 & 42.0 \\
\hline & $1501-2500$ & 132 & 38.8 \\
\hline & 2501 and above & 65 & 19.2 \\
\hline \multirow{4}{*}{ Educational Background } & Primary Education & 9 & 2.6 \\
\hline & Secondary school & 79 & 23.2 \\
\hline & University & 209 & 61.5 \\
\hline & Postgraduate & 43 & 12,6 \\
\hline \multirow{3}{*}{ Period of Membership } & $1-2$ years & 269 & 79.2 \\
\hline & 3-4 years & 57 & 16.8 \\
\hline & $5-6$ years & 14 & 4.0 \\
\hline \multirow{4}{*}{ Frequency of use } & $1-2$ days & 36 & 10,6 \\
\hline & $3-4$ & 196 & 57.6 \\
\hline & 5-6 days & 96 & 28,2 \\
\hline & 7 days & 12 & 3.5 \\
\hline Total & & 340 & 100 \\
\hline
\end{tabular}

As a demographic variable for the participants who did not participate in our research; to question variables such as age, gender, educational status, income status was used in the research. In addition, the Sports Centers participating in the study used the Service Quality Assessment Scale (Lam (2000)), which was translated into Turkish by Gürbüz, Koçak and Lam (2005) to determine the service quality perceptions of sports centers (Gurbuz, Kocak, Lam , 2012) In our study, reliability coefficient of service quality scale was determined as $\alpha=0.79$.

\section{Data Analysis}

In the analysis of the data, the descriptive statistics as well as the Independent Samples T-Test were used to test the difference between the two variables depending on the number of variables, the one-way ANOVA for independent samples, One-way ANOVA) analyzes were used. The findings of the analyzes are placed in a table and discussed.
Questions are asked such as marital status, age, gender, monthly income, education 
Koçak, Y., Tukul, U., Tolan, B., Gümüş, H., Tolukan, E. / Analysis of Expectations and Perceptions of the Customers in Sports and Healthy Life Centers for Service Quality (Sample of Afyonkarahisar Province)

status, occupation, duration of membership, frequency of use.

Table 2. Quality of service by gender of participants $t$ Test Results

\begin{tabular}{|c|c|c|c|c|c|c|}
\hline Quality of Service & Gender & $\mathbf{N}$ & $\mathbf{X}$ & SS & $\mathbf{t}$ & $\mathbf{p}$ \\
\hline \multirow{2}{*}{ Expected from personnel } & Male & 171 & 4.68 & 57 & \multirow{2}{*}{1689} & \multirow{2}{*}{0.092} \\
\hline & Female & 169 & 4.77 & 39 & & \\
\hline \multirow{2}{*}{ Offered by personnel } & Male & 171 & 4.64 & 65 & \multirow{2}{*}{2.130} & \multirow{2}{*}{0.034} \\
\hline & Female & 169 & 4,50 & 52 & & \\
\hline \multirow{2}{*}{ Expected Fitness Program } & Male & 171 & 4.61 & 62 & \multirow{2}{*}{1478} & \multirow{2}{*}{140} \\
\hline & Female & 169 & 4.70 & 42 & & \\
\hline \multirow{2}{*}{ Offered Fitness Program } & Male & 171 & 4.56 & 72 & \multirow{2}{*}{3} & \multirow{2}{*}{0,001} \\
\hline & Female & 169 & 4.29 & 71 & & \\
\hline \multirow{2}{*}{$\begin{array}{l}\text { Expected Quality of the locker } \\
\text { room }\end{array}$} & Male & 171 & 4.76 & 82 & \multirow{2}{*}{394} & \multirow{2}{*}{0.693} \\
\hline & Female & 169 & 4.79 & 42 & & \\
\hline \multirow{2}{*}{$\begin{array}{l}\text { The Quality Of The Locker } \\
\text { Room Offered }\end{array}$} & Male & 171 & 7.68 & 1,12 & \multirow{2}{*}{2} & \multirow{2}{*}{0.043} \\
\hline & Female & 169 & 7.44 & 1.02 & & \\
\hline \multirow{2}{*}{ Expected Facility Quality } & Male & 171 & 4.55 & 58 & \multirow{2}{*}{1} & \multirow{2}{*}{253} \\
\hline & Female & 169 & 4.61 & 52 & & \\
\hline \multirow{2}{*}{ Offered Facility Quality } & Male & 171 & 4.53 & 63 & \multirow{2}{*}{3} & \multirow{2}{*}{0,001} \\
\hline & Female & 169 & 4,31 & 56 & & \\
\hline
\end{tabular}

When service quality is analyzed according to the gender of the customers, it is determined that there is no statistically significant difference among quality of service of all subdimensions $(\mathrm{p}>0.05)$ and there is a statistical significant difference among the expected service quality of all sub-dimensions $(p<0.05)$ and it is determined that there is no statistically significant difference among all- sub-dimensions $(p>0.05)$. This is determined that among them there is a statistically significant difference $(p<0.05)$. Accordingly, it is determined that the quality values of women offered for each sub-dimension are lower than men. In this respect, it is thought that the women have quality expectations in higher ratio than men. 
Koçak, Y., Tukul, U., Tolan, B., Gümüş, H., Tolukan, E. / Analysis of Expectations and Perceptions of the Customers in Sports and Healthy Life Centers for Service Quality (Sample of Afyonkarahisar Province)

Table 3. Service Quality ANOVA results according to the age group of participants

\begin{tabular}{|c|c|c|c|c|c|c|}
\hline AGE & & $\mathbf{N}$ & $\mathbf{X}$ & SS & $\mathbf{F}$ & $\mathbf{p}$ \\
\hline \multirow{3}{*}{ Expected from personnel } & $<25$ & 210 & 4.66 & 52 & \multirow{3}{*}{4.338} & \multirow{3}{*}{0.014} \\
\hline & $25-35$ & 90 & 4,84 & 37 & & \\
\hline & 35 and above & 40 & 4.77 & 48 & & \\
\hline \multirow{3}{*}{ Offered by personnel } & $<25$ & 210 & 53 & 65 & \multirow{3}{*}{2.388} & \multirow{3}{*}{0.093} \\
\hline & $25-35$ & 90 & 4.69 & 45 & & \\
\hline & 35 and above & 40 & 4.51 & 52 & & \\
\hline \multirow{3}{*}{$\begin{array}{l}\text { Expected Fitness } \\
\text { Program }\end{array}$} & $<25$ & 210 & 56 & 57 & \multirow{3}{*}{10.024} & \multirow{3}{*}{$\mathbf{0 , 0 0 1}$} \\
\hline & $25-35$ & 90 & 4.85 & 36 & & \\
\hline & 35 and above & 40 & 4.68 & 53 & & \\
\hline \multirow{3}{*}{ Fitness Program Offered } & $<25$ & 210 & 4.43 & 66 & \multirow{3}{*}{217} & \multirow{3}{*}{805} \\
\hline & $25-35$ & 90 & 4.45 & 83 & & \\
\hline & 35 and above & 40 & 4.36 & 82 & & \\
\hline \multirow{3}{*}{$\begin{array}{l}\text { Expected Quality of the } \\
\text { locker room }\end{array}$} & $<25$ & 210 & 4.69 & 54 & \multirow{3}{*}{4} & \multirow{3}{*}{0.011} \\
\hline & $25-35$ & 90 & 4.88 & 30 & & \\
\hline & 35 and above & 40 & 96 & 1.35 & & \\
\hline \multirow{3}{*}{ Locker Room } & $<25$ & 210 & 51 & 1.06 & \multirow{3}{*}{2.455} & \multirow{3}{*}{0.087} \\
\hline & $25-35$ & 90 & 7.76 & 1.09 & & \\
\hline & 35 and above & 40 & 7,35 & 1.09 & & \\
\hline \multirow{3}{*}{$\begin{array}{l}\text { Expected Quality of } \\
\text { Facilities }\end{array}$} & $<25$ & 210 & 52 & 60 & \multirow{3}{*}{4.233} & \multirow{3}{*}{0.015} \\
\hline & $25-35$ & 90 & 4.72 & 44 & & \\
\hline & 35 and above & 40 & 4.60 & 46 & & \\
\hline \multirow{3}{*}{$\begin{array}{l}\text { Offered Quality of } \\
\text { Facilities }\end{array}$} & $<25$ & 210 & 4.42 & 64 & \multirow{3}{*}{1.877} & \multirow{3}{*}{155} \\
\hline & 25-35 & 90 & 4.49 & 50 & & \\
\hline & 35 and above & 40 & 4.27 & 60 & & \\
\hline
\end{tabular}

When service quality is analyzed according to the age group of the customers, it is determined that there a statistically significant difference among quality of service of all subdimensions $(\mathrm{p}<0.05)$ and there is no statistical significant difference among the expected service quality of all sub-dimensions (p>0.05) and it is determined that there is no statistically significant difference among allsub-dimensions ( $p>0.05$ ). Accordingly, it is determined that the quality values of women offered for each sub-dimension are lower than men. In this respect, it is thought that the women have quality expectations in higher ratio than men. 
Koçak, Y., Tukul, U., Tolan, B., Gümüş, H., Tolukan, E. / Analysis of Expectations and Perceptions of the Customers in Sports and Healthy Life Centers for Service Quality (Sample of Afyonkarahisar Province)

Table 4. Service Quality ANOVA results according to the monthly income of participants

\begin{tabular}{|c|c|c|c|c|c|c|}
\hline Monthly Income & & $\mathbf{N}$ & $\mathbf{X}$ & SS & $\mathbf{F}$ & $\mathbf{p}$ \\
\hline \multirow{3}{*}{ Expected from personnel } & 1500 & 143 & 4.59 & 78 & \multirow{3}{*}{1.546} & \multirow{3}{*}{189} \\
\hline & $1501-2500$ & 132 & 4.79 & 33 & & \\
\hline & 2501 and above & 65 & 69 & 42 & & \\
\hline \multirow{3}{*}{ Offered by personnel } & 1500 & 143 & 4,31 & 75 & \multirow{3}{*}{3.697} & \multirow{3}{*}{.006} \\
\hline & $1501-2500$ & 132 & 4,62 & 64 & & \\
\hline & 2501 and above & 65 & 4.68 & 47 & & \\
\hline \multirow{3}{*}{ Expected Fitness Program } & 1500 & 143 & 4.45 & 82 & \multirow{3}{*}{4.003} & \multirow{3}{*}{$\mathbf{0 , 0 0 3}$} \\
\hline & $1501-2500$ & 132 & 4.79 & 35 & & \\
\hline & 2501 and above & 65 & 4.71 & 48 & & \\
\hline \multirow{3}{*}{ Fitness Program Offered } & 1500 & 143 & 4.26 & 75 & \multirow{3}{*}{2.153} & \multirow{3}{*}{$0-074$} \\
\hline & $1501-2500$ & 132 & 4.49 & 69 & & \\
\hline & 2501 and above & 65 & 4.58 & 57 & & \\
\hline \multirow{3}{*}{$\begin{array}{l}\text { Expected Quality of the } \\
\text { locker room }\end{array}$} & 1500 & 143 & 4.57 & 77 & \multirow{3}{*}{1} & \multirow{3}{*}{0.095} \\
\hline & $1501-2500$ & 132 & 4.83 & 42 & & \\
\hline & 2501 and above & 65 & 4.89 & 1.09 & & \\
\hline \multirow{3}{*}{ Locker Room } & 1500 & 143 & 7,50 & 92 & \multirow{3}{*}{0.721} & \multirow{3}{*}{578} \\
\hline & $1501-2500$ & 132 & 63 & 1.19 & & \\
\hline & 2501 and above & 65 & 7,50 & 1.19 & & \\
\hline \multirow{3}{*}{$\begin{array}{l}\text { Expected Quality of } \\
\text { Facilities }\end{array}$} & 1500 & 143 & 4.51 & 81 & \multirow{3}{*}{484} & \multirow{3}{*}{748} \\
\hline & $1501-2500$ & 132 & 4.64 & 56 & & \\
\hline & 2501 and above & 65 & 4.55 & 48 & & \\
\hline \multirow{3}{*}{$\begin{array}{l}\text { Offered Quality of } \\
\text { Facilities }\end{array}$} & 1500 & 143 & 4.35 & 72 & \multirow{3}{*}{274} & \multirow{3}{*}{895} \\
\hline & $1501-2500$ & 132 & 4.46 & 62 & & \\
\hline & 2501 and above & 65 & 4.43 & 62 & & \\
\hline
\end{tabular}

When it is examined according to the monthly income level, is determined that the individuals with high-income expect a better fitness program and accordingly the personnel deal more with the individuals with high income level $(\mathrm{p}<0.05)$. 
Koçak, Y., Tukul, U., Tolan, B., Gümüş, H., Tolukan, E. / Analysis of Expectations and Perceptions of the Customers in Sports and Healthy Life Centers for Service Quality (Sample of Afyonkarahisar Province)

Table 5: Service Quality ANOVA results according to the membership status of participants

\begin{tabular}{|c|c|c|c|c|c|c|}
\hline Membership Status & & $\mathbf{N}$ & $\mathbf{X}$ & SS & $\mathbf{F}$ & $\mathbf{p}$ \\
\hline \multirow{3}{*}{ Expected from personnel } & $1-2$ years & 269 & 4.68 & 53 & \multirow{3}{*}{1652} & \multirow{3}{*}{161} \\
\hline & 3-4 years & 57 & 4.86 & 23 & & \\
\hline & 5-6 years & 14 & 4.91 & 12 & & \\
\hline \multirow{3}{*}{ Offered by personnel } & $1-2$ years & 269 & 57 & 58 & \multirow{3}{*}{1} & \multirow{3}{*}{362} \\
\hline & $3-4$ years & 57 & 69 & 52 & & \\
\hline & $5-6$ years & 14 & 4.67 & 41 & & \\
\hline \multirow{3}{*}{ Expected Fitness Program } & $1-2$ years & 269 & 4.59 & 56 & \multirow{3}{*}{2} & \multirow{3}{*}{0.033} \\
\hline & $3-4$ years & 57 & 4.83 & 43 & & \\
\hline & $5-6$ years & 14 & 5.14 & 40 & & \\
\hline \multirow{3}{*}{ Fitness Program Offered } & $1-2$ years & 269 & 4.42 & 62 & \multirow{3}{*}{1.799} & \multirow{3}{*}{129} \\
\hline & 3-4 years & 57 & 4.67 & 52 & & \\
\hline & 5-6 years & 14 & 4.56 & 81 & & \\
\hline \multirow{3}{*}{$\begin{array}{l}\text { Expected Quality of the locker } \\
\text { room }\end{array}$} & $1-2$ years & 269 & 4.71 & 51 & \multirow{3}{*}{3} & \multirow{3}{*}{0.016} \\
\hline & $3-4$ years & 57 & 4.88 & 1.41 & & \\
\hline & $5-6$ years & 14 & 5.16 & 12 & & \\
\hline \multirow{3}{*}{ Locker Room } & 1-2years & 269 & 7.58 & 95 & \multirow{3}{*}{659} & \multirow{3}{*}{$-\% 621$} \\
\hline & $3-4$ years & 57 & 7.58 & 1.19 & & \\
\hline & 5-6 years & 14 & 7.90 & 71 & & \\
\hline \multirow{3}{*}{ Expected Quality of Facilities } & $1-2$ years & 269 & 4.55 & 53 & \multirow{3}{*}{1.037} & \multirow{3}{*}{.388} \\
\hline & $3-4$ years & 57 & 4.65 & 56 & & \\
\hline & $5-6$ years & 14 & 4.82 & 39 & & \\
\hline \multirow{3}{*}{ Offered Quality of Facilities } & $1-2$ years & 269 & 4.39 & 59 & \multirow{3}{*}{2.092} & \multirow{3}{*}{082} \\
\hline & $3-4$ years & 57 & 4.53 & 53 & & \\
\hline & $5-6$ years & 14 & 77 & 39 & & \\
\hline
\end{tabular}

It is determined that for the individuals starting a new fitness centers, the quality of fitness program is low $(\mathrm{p}<0.05)$, in addition there is no statistically significant difference between the membership status and expected locker room quality.

Table 6. Service quality sub-dimension difference table according to the usage frequency of the participants

\begin{tabular}{|c|c|c|c|c|c|c|}
\hline Frequency of use & & $\mathbf{N}$ & $\mathbf{X}$ & SS & $\mathbf{F}$ & $\mathbf{p}$ \\
\hline \multirow{4}{*}{ Expected from personnel } & $1-2$ & 36 & 4.66 & 77 & \multirow{4}{*}{2.685} & \multirow{4}{*}{0.047} \\
\hline & $3-4$ & 196 & 4.78 & 34 & & \\
\hline & $5-6$ & 96 & 4.64 & 58 & & \\
\hline & 7 & 12 & 4.56 & 56 & & \\
\hline \multirow{4}{*}{ Offered Fitness Program } & $1-2$ & 36 & 94 & 1.07 & \multirow{4}{*}{9.169} & \multirow{4}{*}{0,001} \\
\hline & $3-4$ & 196 & 4.43 & 65 & & \\
\hline & $5-6$ & 96 & 4,62 & 51 & & \\
\hline & 7 & 12 & 4.11 & 1.28 & & \\
\hline
\end{tabular}

It is determined that the expectation of the customers using Sports Halls more often from the personnel is at a higher level $(\mathrm{p}<0.05)$

\section{DISCUSSION AND RESULTS}

Today, the growth of the service sector in the form of generating two-thirds of the trade volume, caused intense competition among and the satisfaction level of individuals using the hall more often is higher $(\mathrm{p}<0.01)$.

businesses in this sector; as a result of this competition, business managers confronted the obligation of providing customer satisfaction with various application that shall survive their businesses (Karl and Peluchette, 
Koçak, Y., Tukul, U., Tolan, B., Gümüş, H., Tolukan, E. / Analysis of Expectations and Perceptions of the Customers in Sports and Healthy Life Centers for Service Quality (Sample of Afyonkarahisar Province)

2006). This situation occurring in the service sector has an importance in same level for the hotel managements forming a branch of service industry and service became an important concept in providing customer satisfaction (Heung and Wong, 1997). Service quality concept is a concept which must be analyzed from a wider perspective in terms of wellness and Sports Center and must be considered substantially.

Total 340 (age: $25.03 \pm 13.34$ ) participants as to be 171 men and 169 women using 11 different wellness centers have participated to this study in which it is aimed to analyze the service quality in sports and wellness center. When Table 2 is analyzed, it is observed that age groups of the participants show some significant differences in sub-dimensions of the service quality. According to this finding, the service quality expected from the personnel, quality of the expected fitness program, expected quality of the locker room and expected quality of facility may change according to the age. It is possible to confront studies supporting these findings. (Eraslan and Çimen, 2016; Aslan and Koçak, 2011).

In another finding of the study, participants' perceptions of service quality were examined according to their income levels and significant differences were found in the expected fitness program sub-dimensions provided by the staff, but no significant difference was found in other dimensions. This finding can be interpreted as the effect of the income variable on the sub-dimensions. The researches of Okumuş and Duygun (2008) are in parallel with our study. In another study, participants' membership year variables were examined and significant differences were found in expected locker room quality subscale and expected fitness program subscale. It can be said that as the year of membership of the participants increased, the quality of the dressing room and the quality program regarding the fitness program increased. According to another finding of the study, no significant difference was found in terms of educational level.

\section{REFERENCES}

Aslan, M., \& Koçak, M. S. (2011). Determination of the service quality among sport and fitness centers of the selected universities. Journal of Human Sciences, 8(2), 817833.

Ceylan, Ö., Yıldız, M.S., Tekin, A. \& Özdağ, S. (2010). Comparions of Tourism using internal and external source in animation in terms of Service Quality Turkey Kickbox Federation Sport Sciences Journal, 2(2), 16-32.

Çimen, Z. (2003). Total Quality Dimensions in Sport Services, İstanbul Üniversity Sport Sciences Journal, 2(13-17).

Çimen, Z., \& Gürbüz, B. (2007). Total Quality Management in Sport Services. Alp Publishing, Ankara.

Demir, Ş. Ş. (2013). Expectation, perceived quality-value and satisfaction relation: An application on Tourism graduate students. International Journal of Human Sciences, 10(1), 307-324.

Eleren, A. \& Kılıç, B. (2007). Measurement of Service Quality and Servqual Analysis in Tourism Sector and Application in a Thermal Hotel. Afyon Kocatepe University, İ̈BF Journal, 9(1), 235-263.

Eraslan, A. \& Çimen, Z. (2016). "The Service Quality of Recreational Sports Centers on University Campuses: Perceptions of Students". International Journal of Recent Scientific Research, 7(7), 12641-12648.

Ersöz, S., Pınarbașı, M., Türker, A.K. \& Yüzükırmızı, M. (2009). "Measurement of Service Quality with Servqual Method and Analysis of the consequences with structural equality models: Öğretmen Evi Uygulaması". International Journal of Research\&Development, 1(1), 19-27.

Gürbüz, B, Koçak S \& Lam T.C.E. (2004). "The Reliability and Validity of the Turkish Version of the Service Quality Assessment Scale", 19th Conference of the North American Society for Sport Management Abstract Book, Atlanta, Georgia.

Kilıç, B. \& Eleren, A. (2010). Measurement of service quality in Thermal Hotel enterprises. Süleyman Demirel University Economics and Administrative Sciences Faculty Journal, 15(3), 119-142.

Murray, D., \& Howat, G. (2002). The Relationship Among Service Quality, Value, Satisfaction, and Future Intentions of Customer at an Australian Sports and 
Koçak, Y., Tukul, U., Tolan, B., Gümüş, H., Tolukan, E. / Analysis of Expectations and Perceptions of the Customers in Sports and Healthy Life Centers for Service Quality (Sample of Afyonkarahisar Province)

Leisure Centre. Sport Management Review, 5, 25-43.

Okumuş, A., \& Duygun, A. (2008). Measurement of service quality in marketing the educational services and relation between the perceived service quality and student satisfaction.

Özkan, I., Özarslan, A., \& Bekler, F. (2015). Physical Activity Sleeping Quality and Depression Relations in University Students. Physical Education and Sport Sciences Journal, 9.

Temizkan, S. P., Ekici, A., \& Demirci, B. (2016). The effects of perceptions related with Turkish Baths on the future intentions in scope of thermak tourism. International Journal of Human Sciences, 13(1),22322246.

Yerlisu Lapa, T. \& Baştaç, E. (2012). Analysis of service quality for the centers according to the age, gender and educations of the individuals in Fitness Centers at Antalya. Pamukkale Journal of Sport Sciences, 3(1), 42-52.

Yıldırım, I., Işık, O., Ersöz, G., Büyükkök, M., Zengin, G. \& Özel, Ö. (2016). Correlation between depression and eating attitudes and behaviors among those who performed regular physical activities. Journal Of Human Sciences, 13, 35903599.

Yıldırım, İ., Özşevik, K., Sultan, Ö., Canyurt, E., \& Tortop, Y. (2015). Physical activity and depression relations in university students. Physical Education and Sport Sciences Journal, 9, 32-39.

Yıldı,, Y., Onag, A.O. \& Onag, Z. (2013). Analysis of service quality in sport and recreation services: Fitness Center example:. International arbitration Human and Academic Sciences Journal, 2(3), 114130. 